\title{
IMMUNOHISTOCHEMICAL DETECTION OF B AND T LYMPHOCYTES IN MANDIBULAR LYMPH NODES OF EXPERIMENTALLY INFECTED PIGLETS WITH CLASSICAL SWINE FEVER VIRUS
}

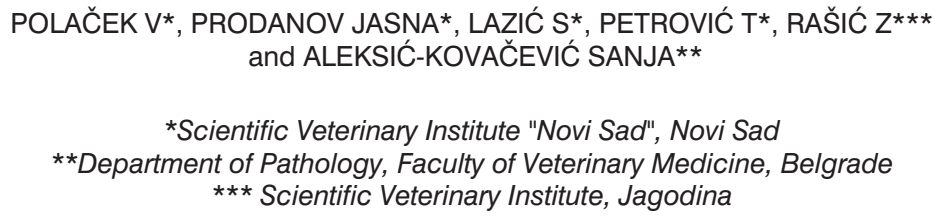

(Received, 8 August, 2006)

Classical swine fever (CSF) is a highly contagious viral disease of domestic pigs and wild boars with severe consequences on animal welfare, livestock production, trade and national economy. We investigated if colostral antibodies in piglets, originating from sows vaccinated with Chine strain (C-strain) and challenged with CSF virus, affected the distribution of the $B$ and $T$ lymhocites in mandibular lymph nodes. Nineteen 45 days old cross breed pigs of both sexes were divided in three groups. All animals in the first group, originating from sows vaccinated with $C$-strain vaccine were serologically positive for the presence of specific colostral CSF virus antibodies. The second group consisted of pigs originating from unvaccinated sows serologically negative for CSF virus antibodies. Three healthy pigs serologically negative for the presence of CSF virus antibodies, originating from unvaccinated sows against CSF virus served as a control group. In the group of animals originating from unvaccinated sows against CSF, severe depletion of CD79 positive B lymphocytes was detected. In the group of pigs originating from sows vaccinated with $C$-strain (CSF virus antibody positive group of pigs), a reduced number of CD79 positive $B$ lymphocytes was detected, but $B$ cells were still present in the periphery of the germinative centres of secondary lymph follicles. There was an increase of the number of CD3 positive cells in the mandibular lymph nodes of pigs with or without maternal antibodies.

Key words: B lymphocytes; classical swine fever; lymphoid depletion; $T$ lymhocites

\section{INTRODUCTION}

Classical swine fever (CSF) is a highly contagious viral disease of domestic pigs and wild boars. The causative agent is the virus (CSFV) that belongs to the genus Pestivirus of the Flaviviridae family (van Oirschot, 1999, 2003; Paton and Greiser-Wilke, 2003). CSF has severe consequences on animal welfare, livestock production, trade and national economy (Moenning, 2000). During CSFV 
infection lymphoid organs are depleted from lymphocytes while in the peripheral blood severe lymphopenia develops (Šuša et al., 1992; Sato et al., 2000; Summerfiled et al., 2000; Sánchez-Cordón et al., 2002, 2005). Such an event contributes to the transient immunosuppresion and is most likely the cause of delayed immune response in infected animals (Sánchez-Cordón et al., 2006). Monocytic and immature granulocytic cells have been recognized to be infected with the virus (Summerfiled et al., 1998) as well as vascular endothelial cells, consequently leading to the damage of various tissues. Recently Carrasco et al., provided evidence that dendritic cells are infected with CSFV. Tissue lesions and lymphocyte distribution depend on the virulence of the virus (Narita et al., 2000). In countries where CSFV has not been eradicated, a vaccination program with the attenuated live vaccine (mostly with Chine strain) is established. In such circumstances colostral antibodies are expected to protect piglets up to a certain level. We wanted to know if colostral antibodies in piglets, originating from sows vaccinated with Chine strain (C-strain) and challenged with CSF virus, affected the distribution of $B$ and $T$ lymhocites in mandibular lymph nodes.

\section{MATERIAL AND METHODS}

Animals, virus and experimental design

Nineteen 45 days old Landrace $\times$ Large White pigs of both sexes were divided in three groups. All eight animals in the first group originating from pigs vaccinated with $\mathrm{C}$-strain vaccine were serologically positive for the presence of specific colostral antibodies on CSFV. The second group consisted of eight pigs originating from unvaccinated sows serologically negative for the presence of CSFV antibodies. Three healthy pigs unvaccinated against CSF, originating from unvaccinated sows were in the third, control group. All the animals were serologically negative for the presence of BVDV antibodies. The animals were housed in the Experimental-Diagnostic-Center of the Scientific Veterinary Institute "Novi Sad", Novi Sad.

Each of the sixteen animals received intramuscular inoculation of $2 \times 10^{5} \mathrm{TCDI} / 50$ of CSFV, Baker strain, while three control pigs received only $1 \mathrm{~mL}$ of phosphate buffered saline (PBS), $\mathrm{pH} 7.2$, on the $55^{\text {th }}$ day of life. After virus inoculation clinical signs and rectal temperature were monitored daily. All experimentally infected pigs died before the $22^{\text {nd }}$ day post infection (pid). Euthanasia of pigs in the control group was performed with an intravenous injection of T61 (Intervet, International) at the end of the study.

\section{Blood collection and specific antibody detection in serum}

Pre-inoculated blood samples were taken from the jugular vein of all pigs. Specific CSFV antibodies in the sera were determined by the IDEXX ${ }^{\circledR}$ Classical Swine Fever Virus Antibody Test Kit according to the manufacturers instructions. Detection of specific antibodies to the Bovine Viral Diarrhea Virus (BVDV) was performed by VN test with NADL strain, according to the procedure described in the Manual of Diagnostic Tests and Vaccines for Terrestrial Animals, Office International Des Epizooties (2004). 
Acta Veterinaria (Beograd), Vol. 57, No. 2-3, 199-208, 2007.

\section{Histopathology and immunohistochemistry}

Samples were taken from the mandibular lymph nodes after necropsy. Specimens were fixed for two days in $10 \%$ neutral formalin. The samples were dehydrated through graded series of alcohol and embedded in paraffin wax by routine techniques for light microscopy. Wax embedded sections (4im) were cut and stained with haematoxylin and eosin (HE).

For the detection of CSFV glycoprotein E2(gp55) the monoclonal antibody WH303 (Veterinary Laboratories Agency, Addlestone, UK) was used. To demonstrate $\mathrm{T}$ and $\mathrm{B}$ lymphocytes, monoclonal mouse anti-human CD3 and CD79 antibodies (DAKO Citomation, Danmark) were used. Tissue sections were dewaxed and rehydrated in xylene and in a graded series of alcohol. Citric buffer was used for antigen retrieval by incubation in a microwave oven (560W) for 21 minutes. Endogenous peroxidase activity was abolished by incubation of tissue sections with $0.5 \%$ hydrogen peroxide in methanol for 15 minutes at room temperature. All tissue sections were incubated with $50 \%$ normal goat serum for 30 minutes at room temperature. Primary antibody $\mathrm{WH} 303$ was diluted 1:50 in PBS containing $10 \%$ normal goat serum and incubated for 18 hours at $4^{\circ} \mathrm{C}$. Monoclonal antibodies for CD3 and CD79 were diluted 1:50 in PBS and incubated for 60 minutes at room temperature. Biotinylated goat anti-mouse immunoglobulin (DAKO, ChemMate, Danmark) was applied as the secondary antibody for 20 minutes at room temperature.

All tissue sections were incubated with streptavidin-peroxidase complex (DAKO, Danmark) for 20 minutes at room temperature and with chromogen 3-3' diaminobenzidine tetrahydrochloride (DAKO, Liquid DAB, Danmark) or 3-amino-9 etilcarbamasole (DAKO, ChemMate, AEC, Danmark) and counterstained with Mayer's haematoxylin. Details of the primary antibodies, including dilutions and pre-treatments, are summarized in Table 1.

Table 1. Details of the immunolabeing reagens

\begin{tabular}{|l|c|c|c|c|}
\hline \multicolumn{1}{|c|}{$\begin{array}{c}\text { Primary } \\
\text { antibody }\end{array}$} & $\begin{array}{c}\text { Chemical } \\
\text { fixation }\end{array}$ & $\begin{array}{c}\text { Antigen or cell de- } \\
\text { tected }\end{array}$ & $\begin{array}{c}\text { Antibody } \\
\text { dilution }\end{array}$ & $\begin{array}{c}\text { Pre- } \\
\text { treatment }\end{array}$ \\
\hline $\begin{array}{l}\text { Monoclonal } \\
\text { WH303* }\end{array}$ & $\begin{array}{c}\text { Neutral formalin } \\
\text { solution } 10 \%\end{array}$ & $\begin{array}{c}\text { CSFV protein } \\
\text { E2(gp55) }\end{array}$ & 1 in $50^{!}$ & $\begin{array}{c}\text { Citrate } \\
\text { buffer }\end{array}$ \\
\hline $\begin{array}{l}\text { Monoclonal mouse } \\
\text { anti-human CD3** }\end{array}$ & $\begin{array}{c}\text { Neutral formalin } \\
\text { solution } 10 \%\end{array}$ & $\begin{array}{c}\text { CD3 } \\
\text { (T lymphocytes) }\end{array}$ & 1 in $50^{! !}$ & $\begin{array}{c}\text { Citrate } \\
\text { buffer }\end{array}$ \\
\hline $\begin{array}{l}\text { Monoclonal mouse } \\
\text { anti-human CD79*** }\end{array}$ & $\begin{array}{c}\text { Neutral formalin } \\
\text { solution } 10 \%\end{array}$ & $\begin{array}{c}\text { CD79 } \\
\text { (B lymphocytes) }\end{array}$ & 1 in $50 ! !$ & $\begin{array}{l}\text { Citrate } \\
\text { buffer }\end{array}$ \\
\hline
\end{tabular}

! In PBS (pH 7.2) containing normal goat serum $10 \%$

!! In PBS (pH 7.2) The Labeled streptavidin-biotin complex (LSAB) method (ChemMate, DAKO, Danmark, product No. K5003) was used with 3-3' diaminobenzidine tetrahydrochloride (DAKO, Liquid DAB, Danmark, product No. K3465) or 3-amino-9 etilcarbamasole (AEC, ChemMate, DAKO Danmark, product No. K5003)

* Veterinary Laboratory Agency, Addlestone, UK, product No.PA0826

** DAKO, Danmark product No. A0452

*** DAKO, Danmark product No. M7051 


\section{Detection of viral RNA}

RNA was extracted from tissues using Trizol reagent (GIBCO BRL) according to manufacturer's recommendation. Briefly, three volumes of Trizol reagent were added to $250 \mu \mathrm{L}$ of sample material (supernatant from $10 \%$ tissue homogenate in PBS). This was then extracted sequentially with chloroform and isopropanol and then RNA was precipitated with $80 \%$ ethanol prior to resuspension in DEPC treated water.

The "one-tube" or "one-step RT-PCR" assay was performed by using reagents supplied in a commercial "Access RT-PCR system" (Promega, USA) according to the manufacturer's instruction. RT-PCR amplification was done using E2 gene specific primers described by Katz et al. (1993): gp55-U: 5'-ATA TAT GCT CAA GGG CGA GT-3' (sense, position in genome of the Alfort strain is 3378-3397); gp55-L: 5'-ACA GCA GTA GTA TCC ATT TCT TTA-3' (antisense, position in genome of the Alfort strain is 3685-3662).

RNA sample $(6 \mu \mathrm{l})$ was added to $44 \mu \mathrm{l}$ reaction mixtures containing AMV/Tfl $1 \times$ reaction buffer, dNTP mix $(10 \mathrm{mM}), 25$ pmol of sense and antisense primer, $1 \mathrm{mM}$ of $\mathrm{MgSO}_{4}, 5 \mathrm{U}$ of AMV RT and $5 \mathrm{U}$ of Tfl DNA polymerase. The RT-PCR cycling conditions were as follows: 45 min at $48^{\circ} \mathrm{C}$ for RT, $94^{\circ} \mathrm{C}$ for 2 min for AMV $\mathrm{RT}$ inactivation and RNA/cDNA/ primer denaturation, 40 cycles of $30 \mathrm{~s}$ at $94^{\circ} \mathrm{C}, 1$ min at $60^{\circ} \mathrm{C}$ and $2 \mathrm{~min}$ at $68^{\circ} \mathrm{C}$, and a final extension step at $68^{\circ} \mathrm{C}$ for $7 \mathrm{~min}$. Amplified products were analyzed by electrophoresis on a 1.5\% agarose gel.

\section{RESULTS AND DISCUSSION}

\section{Clinical signs and gross lesions}

All pigs inoculated with CSFV became ill with characteristic clinical signs of CSF. High body temperature was detected 2 days post-inoculation (dpi). Rectal temperature was between $40.6^{\circ} \mathrm{C}$ and $41.4^{\circ} \mathrm{C}$. Reduced appetite and apathy were noticed from $3 \mathrm{dpi}$. Conjunctivitis associated with eye discharge was recorded from $5 \mathrm{dpi}$. Yellowish gray diarrhea was noticed from 7-8 dpi. In few pigs aphonia developed. Neurological sings (convulsions, staggering gait, posterior paresis) were recorded from 7-14 dpi. Hyperemia, cyanosis and hemorrhages of skin were also noticed from $9 \mathrm{dpi}$. All experimentally infected pigs in both groups died until $22 \mathrm{dpi}$.

The mandibular lymph nodes were swollen and enlarged. Subcapsular to diffuse hemorrhages were found on necropsy which gave an almost dark appearance to the lymph nodes. Mostly, mandibular lymph nodes had a characteristic marbled appearance in cross-section.

\section{Histopathology}

In all experimentally infected pigs with CSFV microscopic changes corresponded with gross lesions. Huge hemorrhages were localized mostly subcapsulary, in the cortex and paracortex. All examined mandibular lymph nodes showed depletion of lymphocytes from follicles and a great number of 
Acta Veterinaria (Beograd), Vol. 57, No. 2-3, 199-208, 2007.

Polaček V et al:: Immunohistochemical detection of B and T lymphocytes in

mandibular lymph nodes of experimentally Infected piglets with classical swine fever virus

macrophages. Edema of endothelial cells with fibrinoid necrosis and thrombosis occurred in small blood vessels.

\section{Detection of viral antigen}

There was no immunolabelling for the glycoprotein E2 (gp55) in the control group of the pigs. Immunohistochemical examination of the mandibular lymph nodes of the experimentally inoculated pigs with CSFV demonstrated E2 (gp55) protein as brown granular intracytoplasmatic deposits of endothelial cells, macrophages (Fig. 1 and Fig. 2), and a large number of lymphocytes and plasma cells around trabeculs and subcapsular sinus (Fig. 2).

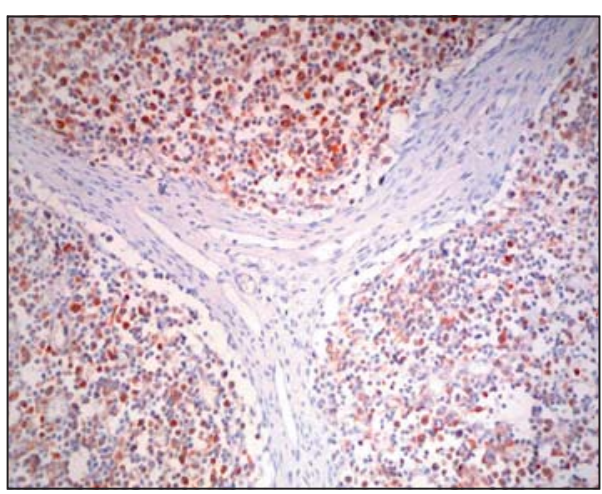

Figure 1. Mandibular lymph node, group with CSFV antibodies, WH303 (against E2 protein of the CSFV), LSAB, $x 400$

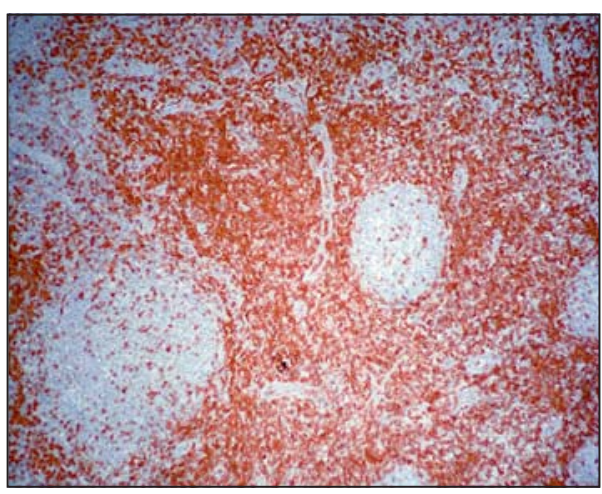

Figure 3. Mandibular lymph node, group without CSFV antibodies, $22 \mathrm{dpi}$, CD3 (against T lymphocytes), LSAB, x100

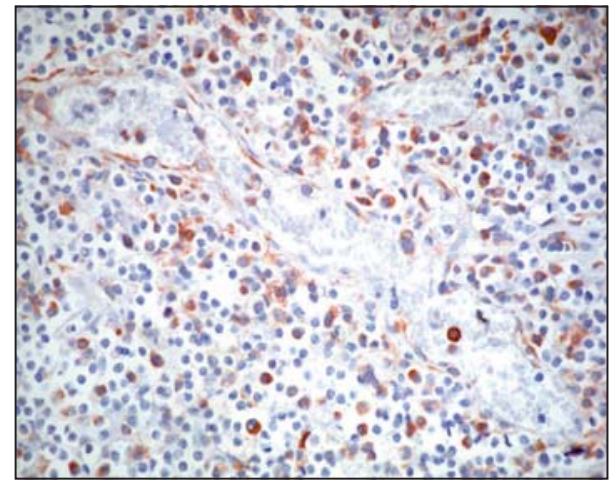

Figure 2. Mandibular lymph node, group without CSFV antibodies, WH303 (against E2 protein of the CSFV), LSAB, x200

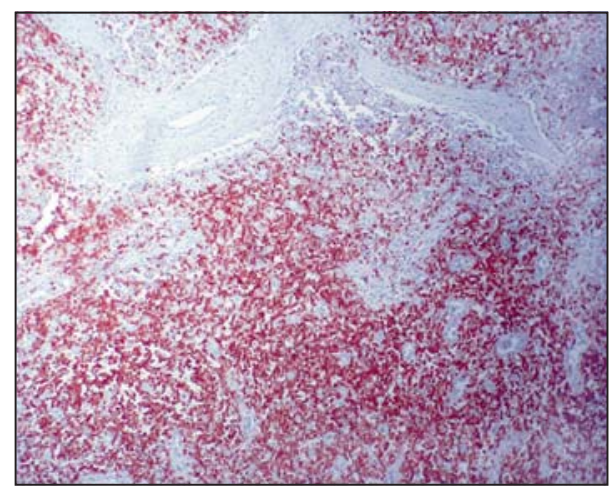

Figure 4. Mandibular lymph node, group with CSFV antibodies, $11 \mathrm{dpi}$, CD3 (against T lymphocytes), LSAB, x100 


\section{Detection of $B$ and $T$ lymphocytes in mandibular lymph nodes}

The immunohistochemical detection of CD3 T lymphocytes in mandibular lymph nodes showed an increase in the number of CD3 T lymphocytes mostly around trabecules in both groups of experimental pigs (Fig. 3 and Fig. 4). Depletion of CD79 positive B lymphocytes was determined in both groups of pigs in the mandibular lymph nodes. In the group of animals originating from unvaccinated sows, (CSFV antibodies free group of experimental pigs), more severe depletion of CD79 positive B lymphocyte was detected (Fig. 6). On the other hand in the group of pigs originating from sows vaccinated with C-strain, (group of experimental pigs with the presence of the CSFV colostral antibodies), a reduced number of CD79 positive $B$ lymphocytes was detected but CD79 positive B lymphocytes were still present in the periphery of germinative centres of the secondary lymph follicles of mandibular lymph nodes (Fig. 7).

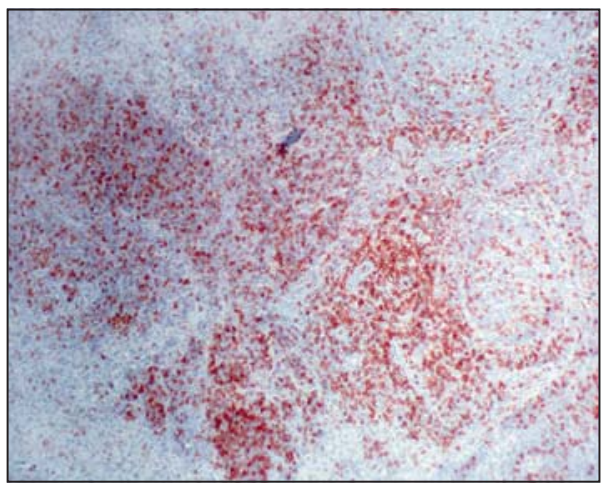

Figure 5. Mandibular lymph node, control group, CD3 (against T lymphocytes), LSAB, x100

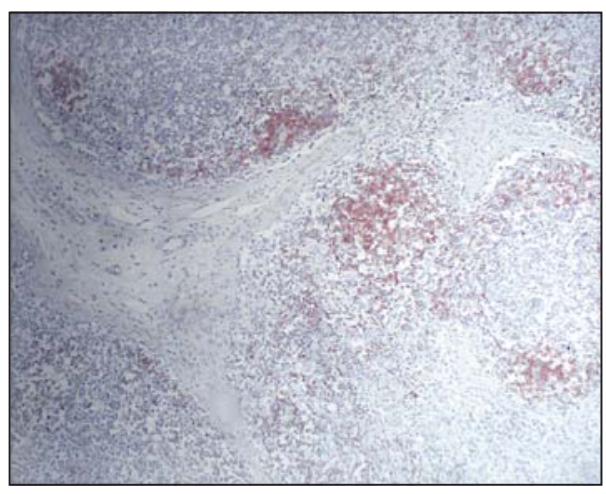

Figure 7. Mandibular lymph node, group with CSFV antibodies, $11 \mathrm{dpi}$, CD79 (against B lymphocytes), LSAB, x100

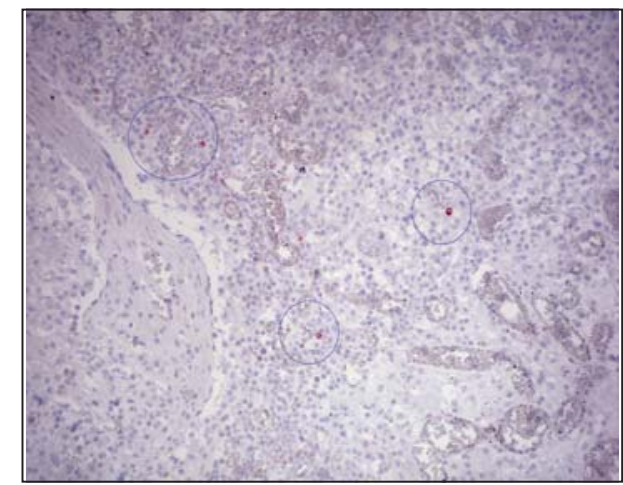

Figure 6. Mandibular lymph node, group without CSFV antibodies, $16 \mathrm{dpi}$, CD79 (against B lymphocytes), LSAB, $\mathrm{x} 100$. Note just a few positive $B$ cells

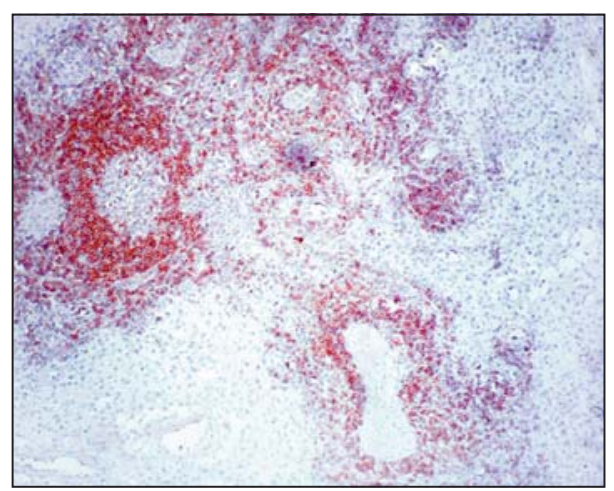

Figure 8. Mandibular lymph node, control group, CD79 (against B lymphocytes), LSAB, x100 
Acta Veterinaria (Beograd), Vol. 57, No. 2-3, 199-208, 2007.

Polaček V et al:: Immunohistochemical detection of B and T lymphocytes in

mandibular lymph nodes of experimentally Infected piglets with classical swine fever virus

\section{Detection of viral RNA}

In all the samples taken from pigs inoculated with CSFV, the RNA virus was found. The samples of mandibular lymph nodes and brain taken from pigs in the control group were negative for the presence of CSFV RNA.

Mandibular lymph nodes from both groups of piglets were depleted from $B$ lymphocytes. More severe depletion of CD79 positive B lymphocytes was present in the second group of animals (free from CSFV antibodies) where only few immunolabeled cells for CD79 were determined. Our results are in correlation with results reported by Narita et al., 2000. The authors discovered total depletion of B lymphocytes in lymph nodes of pigs infected with the highly virulent strain, and moderate depletion of $B$ lymphocyte in the lymph nodes of pigs injected with the less virulent strain of CSFV. The depletion of CD79 positive B lymphocytes could have affected the delayed humoral response of pigs infected with CSFV (Sánchez-Cordón et al., 2006). There is an initial depletion of T and B cells in the peripheral blood during CSF infection (Summerfield et al., 2001). Here we provide the evidence that at the site of viral multiplication, i.e. lymph node, there is an increase of activated CD3 cells comparing to that in the controls. This is supported by the fact that CD3 positive cells practically replace $B$ cells. We assume that as disease progresses, $T$ cells activated at the site of virus multiplication and are most likely directly involved in the immune response. In the study of SánchezCordón et al., 2005, the role of monocyte/macrophage cells lineage and secretion of cytokines in the spleen from CSFV infected pigs was determined. The presence of viral antigens was necessary to induce TNF- $\alpha$ expression. TNF is cytokine involved in inflammatory response and its role is tightly connected with the induction of apoptosis. Since in our experiments maternally immune piglets had clinical evidence of the disease a few days later than the non-immune animals, we assume that passively transferred antibodies neutralized the virus to a certain level but could not prevented the fatal outcome of the disease. Also, the neutralizing activity of passively transferred antibodies prevented the total destruction of B lymphocytes but did not affect CD3 T lymphocytes presence in the lymph node. This result leads to the speculation that T cells per se are not the only cells responsible for $\mathrm{B}$ cell destruction. One possible explanation is that the signal for apoptosis comes from macrophages and that these cells probably produce a lower amount of TNF $\alpha$ in maternally immune piglets. The exact role of T cells in tissues during the course of CSFV infection needs to be evaluated in the future.

All infected piglets (with or without passive antibodies) during this experiment succumbed to the disease. The only difference was found during the pathohistological examination in CD79 depletion in the lymph nodes. We did not measure the titer of CSFV antibodies before challenge since ELISA kit detected only the presence or absence of antibodies. In the experiment of Terpsta and Wensvoort (1988) CSFV antibody titer of $1 / 32$ could prevent both clinical signs of diseases and the horizontal spread of the virus. Obviously, the amount of colostral CSFV antibodies in the blood of inoculated pigs originating from vaccinated sows with C-strain was not sufficient to prevent clinical signs of CSF. 
In conclusion we found that depletion of B lymphocytes (CD79) was severe in the second group of piglets (without maternally derived antibodies), while in the group of piglets with maternal antibodies the depletion of $B$ lymphocytes was less severe. A significant amount of CD3 lymphocytes was detected in all infected piglets in lymph nodes where a high expression of E2(gp55) was determined. The role of activated CD3 T cells in the lymph node should be elucidated in the future.

\section{ACKNOWLEDGEMENT:}

The research reported here was supported by grant from the Ministry of Science and Environmental Protection (TR-6860B), Republic of Serbia.

Address for correspondence:

Vladimir Polaček, MSc, Research Associate

Scientific Veterinary Institute "Novi Sad"

Rumenački put 20

21000 Novi Sad

Serbia

e-mail: vlade@niv.ns.ac.yu

\section{REFERENCES}

1. Carrasco L, Ruiz-Villamor E, Gómez-Villamandos JC, Bautista MJ, Núñez A et al, 2001, Atypical cilia in the bronchiolar epithelium of pigs experimentally infected with hog cholera virus, $J$ Comp Path, 124, 29-35.

2. Carrasco CJ, Rigden RC, Vincent IE, Balmelli C, Ceppi M et al, 2004, Interaction of classical swine fever virus with dendritic cells, J Gen Virol, 85,1633-41.

3. Gómez-Villamandos JC, Ruiy-Villamor E, Bautista MJ, Quezada M, Sánchez CP et al, 2000, Pathogenesis of Classical Swine Fever. Renal Haemorrages and Erythrodiapedesis, J Comp Path, 123, 47-54.

4. Gómez-Villamandos JC, Ruiz-Villamor E, Salguero FJ, Bautista MJ, Carrasco L et al,1998, Immunohistochemical and ultrastructural evidence of hog cholera virus infection of megakaryocytes in bone marrow and spleen, J Comp Path,119, 111-19.

5. Gómez-Villamandos JC, Ruiz-Villamor E, Bautista MJ, Sánchez CP, Sánchez-Cordon PJ et al, 2001, Morphological and immunohistochemical changes in splenic macrophages of pig infected with Classical Swine Fever, J Comp Path, 125, 98-109.

6. Gómez-Villamandos JC, Ruiz-Villamor E, Bautista MJ, Quezada M, Sánchez CP al, 2000, Pathogenesis of classical swine fever. renal haemorrhages and erythrodiapedesis. $J$ Comp Path, 123, 47-54.

7. Gómez-Villamandos JC, Salguero FJ, Ruiz-Villamor E, Sánchez CP, Bautista MJ et al, 2003, Classical swine fever: pathology of bone marrow, Vet Pathol, 40,157-63.

8. Moennig V, 2000, Introduction to classical swine fever: virus, disease and control policy, Vet Microbiol, 73, 93-102.

9. Narita M, Kawashima K, Shimizu M, 1996, Viral antigen and B and T lymphocytes in lymphoid tissues of gnotobiotic piglets infected with Hog cholera virus, J Comp Path, 114, 257-63.

10. Narita M, Kawashima K, Kimura K, Mikami O, Shibahara $T$ et al, 2000, Comparative immunohistopathology in pigs infected with highly virulent or less virulent strains of hog cholera virus, Vet Pathol, 37, 402-8.

11. Narita M, Kimura K, Tanimura N, Ozaki H, 1999, Immunohistochemical Detection of Hog Cholera Virus Antigen in Paraffin Wax-embedded Tissues from Naturally Infected Pigs, J Comp Path, 121, 283-86. 
Acta Veterinaria (Beograd), Vol. 57, No. 2-3, 199-208, 2007.

12. Núñez A, Gómez-Villamandos JC, Sánchez-Cordon PJ, Fernandez de Marco M, Pedrera $M$ et al, 2005, Expression of Proinflammatory Cytokines by Hepatic Macrophages in Acute Classical Swine Fever, J Comp Path, 133, 23-32.

13. Paton D J, Greiser-Wilke I, 2003, Classical swine fever - an update, Res Vet Sci, 75, 169-78.

14. Ruiz-Villamor E, Quezada M, Bautista MJ, Romanini S, Carrasco L et al, 2001, Classical swine fever: pathogenesis of glomerular demage and immunocharacterization of immunocomplex deposits, J Comp Path, 124, 246-54.

15. Sánchez-Cordón PJ, Romero-Trevejo JL, Pedrera M, Raya Al, Gómez-Villamandos JC, 2006, The Role of B Cells in the Immune Response to Pestivirus (Classical Swine Fever Virus), J Comp Path, 135, 32-41.

16. Sánchez-Cordón PJ, Núñez A, Salguero FJ, Carrasco L, Gómez-Villamandos JC, 2005, Evolution of T Lymphocytes and Cytokine Expression in Classical Swine Fever (CSF) Virus Infection, $J$ Comp Path, 123, 249-60.

17. Sánchez-Cordón PJ, Romanini S, Salguero FJ, Ruiz-Villamor E, Carrasco L, Gómez-Villamandos JC, 2003, Histopathological, immunohistochemical and ultrastructural study of intestine in pigs inoculated with Classical swine fever virus, Vet Pathol, 40, 254-62.

18. Sánchez-Cordón PJ, Romanini S, Salguero FJ, Núñez A, Bautista MJ, Jover A et al, 2002, Apoptosis of thymocytes related to cytokine expression in experimental Classical Swine Fever, J Comp Path, 127, 4, 239-48.

19. Sato M, Mikami O, Kobayashi M, Nakajima Y, 2000, Apoptosis in the lymphatic organs of piglets inoculated with classical swine fever virus, Vet Microbiol, 75, 1-9.

20. Summerfield A, Zingle K, Inumaru S, McCullough KC, 2001, Induction of apoptosis in bone marrow neutrophil-lineage cells, by classical swine fever virus, J Gen Virol, 82, 1309-18.

21. Summerfield A, Knotig SM, McCullough KC, 1998, Lymphocyte apoptosis during Classical Swine Fever. Implication of activation-induced cell death, $J$ Virol, 72, 2, 1853-61.

22. Šuša M, Konig M, Saalmuller A, Reddehase MA, Thiel HJ, 1992, Pathogenesis of Classical swine fever: B-lymphocyte deficiency caused by hog cholera virus, J Virol, 66, 1171-75.

23. Trautwein G, 1988, Pathology and Pathogenesis of the disease, In: Ed Liess B, Classical Swine Fever and related Viral Infections, Martinus Nijhoff Publishing, Boston.

24. Van Oirschot JT, 1999, Classical Swine Fever (Hog Cholera), In: Ed. B. E. Straw, Diseases of Swine, 8th Edition, Blackwell Science.

25. Van Oirschot JT, 2003, Vaccinology of swine fever: from lab to field, Vet Microbiol, 96, 367-84.

\title{
IMUNOHISTOHEMIJSKO DOKAZIVANJE B I T LIMFOCITA U MANDIBULARNOM LIMFNOM ČVORU PRASADI EKSPERIMENTALNO INFICIRANIH VIRUSOM KLASIČNE KUGE SVINJA
}

\author{
POLAČEK V, PRODANOV JASNA, LAZIĆ S, PETROVIĆ T, RAŠIĆ Z \\ i ALEKSIĆ-KOVAČEVIĆ SANJA
}

\section{SADRŽAJ}

Klasična kuga svinja (KKS) je infektivno virusno oboljenje domaćih i divljih svinja, koja ima značajan uticaj kako sa stanovišta dobrobiti životinja, tako i sa stanovišta svinjarske proizvodnje, trgovine i nacionalne ekonomije. Želeli smo da ustanovimo da li specifična kolostralna antitela prasadi poreklom od krmača 
vakcinisanih sa Kina sojem ( $\mathrm{K}$ soj) vakcinom protiv KKS, utiču na distribuciju B i T limfocita u mandibularnom limfnom čvoru, nakon veštačke infekcije sa virusom KKS. Devetnaest prasadi starosti 45 dana, podeljeni su u tru grupe. Jedinke iz prve grupe poticala su od krmača vakcinisanih K sojem protiv KKS i bila su serološki pozitivna na prisustvo specifičnih kolostralnih antitela protiv virusa KKS. Drugu grupu sačinjavala su prasad poreklom od nevakcinisanih krmača protiv KKS, koja su bila serološki negativna na prisustvo specifičnih antitela protiv virusa KKS. Tri zdrave jedinke poreklom od nevakcinisanih krmača, koja su bila serološki negativna na prisustvo antitela protiv virusa KKS predstavljale su kontrolnu grupu. U grupi životinja poreklom od nevakcinisanih krmača protiv KKS, utvrđena je deplecija B limfocita najvećeg stepena. U grupi životinja poreklom od krmača vakcinisani sa K sojem, utvrđeno je izražano smanjenje broja CD79 pozitivnih limfocita, ali su $B$ limfociti $i$ dalje ostali prisutni na periferiji germinitivnih centara sekundarnih limfnih folikula. Broj CD3 pozitivnih T limfocita u mandibularnim čvorovima bio je uvećan u obe grupe eksperimentalno inficiranih životinja sa virusom KKS u odnosu na kontrolnu grupu. 